\title{
Practices of Penalty Imposition by Judge under Minimum Limitation in the Context of Justice
}

\author{
Ramiyanto \\ Faculty of Law, Universitas Sjakhyakirti, Palembang, Indonesia \\ Email: ramiyanto90@gmail.com
}

\begin{abstract}
A special minimum penalty is a penal provison that used in a special law which formulation determines minimum limits. Although the law has specified minimum penalty limits, in practice there has been penalty imposition by a judge below the specified minimum threshold. The question is "Can the judge impose a penalty below the specified minimum limit in the law?". From the outcome of discussion, it can be concluded that the judge may impose a penalty below the specified minimum limits in the law. The permissibility of imposing a penalty below a special minimum limit in accordance with the relative/elastic/uncertain model of unfixed sentence. It has also agreed upon in practice as summarized by the result of the National Working Meeting of the Supreme Court with the Court of Appeal. In bringing the verdict, the judge not only looks at the sound of law, but also has to consider the sense of community justice. Penalty imposition below specified minimum threshold can only be made on the basis of fairness and fact of balance between the actor's error rate and the circumstances surrounding it. Thus, judging from the aspect of justice and the fact of balance between the level of wrongdoers and the circumstances surrounding them, penalty imposition below a special minimum can be done. Penalty imposition below the specified minimum threshold is casuistic (not generally applicable), which means only for certain cases.
\end{abstract}

Keywords_Penalty Imposition; Special Minimum System; Justice

\section{INTRODUCTION}

Penalty is a typical term used in criminal law which refers to sanction or punishment. Reference [13], [14] argues that what distinguishes between criminal law and other law is a sanction in the form of penalty which is threatened against norm violator. Sanction in criminal law is a negative sanction, so it belongs to negative sanction system.

The criminal law applied in Indonesia is the Criminal Code and laws which are out of the Criminal Code or special criminal law (lex specialist). The formulation of criminal sanctions in the special deviates from the formulation of sanctions in the Criminal Code. The formulation of criminal sanctions in specific criminal laws that deviate from the Criminal Code is the formulation of criminal sanctions with a specified minimum system. The formulation system is not known in the Criminal Code. Criminal sanctions formulated with a specified minimum system mean minimum criminal restrictions determined is only for one particular offense.

In the Criminal Code, the criminal sanction system with minimum system is also known, but its general character is not specified. It means that, the minimum penalty arranged in the Criminal Code applies to all offenses listed in the articles of the Criminal Code. The minimum penalty period arranged in the Criminal Code applies to imprisonment and detention. The minimum imprisonment is arranged in Article 12 Section (2) of the Criminal Code which formulation "the length of imprisonment is at least one day and at most fifteen years." Then for the minimum detention arranged in Article 18
Section (1) of the Criminal Code which formulation "duration of imprisonment is at least one day and at most one year ".

Based on the Article 12 Section (2) and Article 18 Section (1) of the Criminal Code above, the minimum limit of imprisonment and detention is during one day. On the Article 97 of the Criminal Code, it is explained that a day is a twenty-four-hour period. Thus, the minimum threshold of imprisonment and detention is during one day or 24 hours. Reference [8] explains that a person getting one day's detention means he or she has to serve the sentence for 24 hours.

Along with the development of era, in some special criminal laws concerning the minimum limit of criminal sanctions is formulated with a special minimum system. Although criminal sanctions in specific criminal laws have been formulated the minimum threshold in particular, but in practice there is a criminal offense under a special minimum. One of them can be seen in the decree no. $1554 \mathrm{~K} / \mathrm{Pid} . S u s / 2014$. In that decree, the defendant was charged by the attorney general with Article 49 Section (2) letter $\mathrm{b}$ of constitution of Republic of Indonesia no. 10, 1998 about the Amendment of Law No. 7 of 1992 concerning Banking (Law No. 10, 1998) Jo. Article 55 Section (1) Jo.Article 64 Section (1) of the Criminal Code.

Criminal sanction in Article 49 Section (2) letter b Law no. 18 of 1998 has been formulated with a special minimum system, which is at least 3 three years. Nevertheless, the panel of judge imposes the conditional detention to the defendant. Based on the Article 14A Section (1) of the Criminal Code, a judge may be able to impose a conditional imprisonment if it is imposed for two 
years. In the decree no.1554K/Pid.Sus/2014, the panel of judge imposes imprisonment to defendant for 6 months. It means that the panel of judge has imposed the imprisonment under a special minimum requirement for 3 years.

From the condition above, the statement "Does the specified minimum penalty be imposed under the specified minimum limit?". Therefore, the author is interested to examine the penalty imposition under special minimum. In this discussion, it will be related to the aspect of justice, whether the imposition of penalty under the specified minimum threshold can be conducted when it is viewed from the aspect of justice.

\section{RESEARCH METHOD}

This study uses a type of normative legal research (library law research) because the object of the study is positive law. The research approach used is a law approach, conceptual approach, and philosophical approach. The type of data in this study is secondary data sourced from three legal materials, namely sources of primary legal materials, secondary legal materials, and tertiary legal materials. The data is collected with document study techniques or literature studies. The collected data is then processed and analyzed qualitatively by legal interpretation techniques. Furthermore, the data that has been analyzed, drawn to a conclusion with the method of deductive thinking, namely the logic of thinking that starts from things that are general and then applied to things that are specific.

\section{RESULT AND DISCUSSION}

\section{A. Arrangement of Specified Minimum Penalty in Special Law Out of the Criminal Code}

On the previous page it has been explained that the specified minimum penalty is written in the special law as a deviation from the Criminal Code. The special minimum penalty is a new thing because it is not known in the Criminal Code as a general criminal law (lex generalist) applied in Indonesia. A specified minimum penalty may be defined as a criminal sanction formulation system which is set for its minimum limits for offenses set out in one article in one law. This is in contrast to the minimum penalty determined in the Criminal Code, which applies to all offenses listed in the Criminal Code.

According to [3], [4] in principle, a special minimum penalty is an exception, namely for certain offenses considered to be very harmful, harmful or disturbing the society and the offenses that are qualified or exacerbated by the consequences (erfolgsqualifizierte delikte). Furthermore, [3], [4] that the minimum requirement (minimum) can be felt from public unrest or dissatisfaction toward the imprisonment that has been imposed practically, especially the penalty that is not much different between the amateur perpetrator criminal and professional perpetrator penalty.

Being related to penalty formulation, there are many special laws that follow the specified minimum system, but knowing the arrangement of specified minimum penalty is limited for some special laws, namely:

1. The Law Number 31 of 1999 of the Republic of Indonesia concerning Elimination of Corruption (Law No. 31 of 1999);

2. The Law Number 20 of 2001 of the Republic of Indonesia concerning Change of the Law Number 31 of 1999 concerning Elimination Corruption (Law No. 20 of 2001);

3. The Law Number 23 of 2004 of the Republic of Indonesia concerning Elimination of Domestic Violence (Law No. 23 of 2004);

4. The Law Number 18 of 2013 of the Republic of Indonesia concerning Prevention and Elimination of Damaing Forest (Law No. 18 of 2013);

5. The Law Number 32 of 2009 of the Republic of Indonesia concerning Protection and Management of Environment (Law No. 32 of 2009);

6. The Law Number 7 of 1992 of the Republic of Indonesia concerning Banking (Law No. 7 of 1992);

7. The Law Number 10 of 1998 of the Republic of Indonesia concerning Change of The Law Number 7 of 1992 concerning Banking (Law No. 10 of 1998);

8. The Law Number 23 of 2002 of the Republic of Indonesia concering Children's Protection (Law No. 23 of 2002);

9. The Law Number 35 of 2014 of the Republic of Indonesia concerning Change of The Law Number 23 of 2002 concerning Children's Protection (Law No. 35 of 2014);

10. The Law Number 35 of 2009 of the Republic of Indonesia concerning Narcotic (Law No. 35 of 2009).

If some of these special laws are reviewed, not all articles in the law adopt a special minimum system in formulating criminal sanctions. Then if it is reviewed by the type, the penaltyl is formulated with a specified minimum system of imprisonment and forfeit. To clarify the regulation regarding specified minimum threshold of imprisonment and forfeit in certain special criminal laws, the authors describe in the following table:

TABLE 1. MINIMUM PENALTY THRESHOLD

\begin{tabular}{|c|l|l|l|}
\hline \multirow{2}{*}{$\begin{array}{c}\text { N } \\
\mathbf{o}\end{array}$} & \multicolumn{1}{|c|}{ Law } & \multicolumn{1}{|c|}{ Minimum Threshold } \\
\hline 1 & $\begin{array}{l}\text { Law No. 31 of } \\
\text { 1999 Jo. Law } \\
\text { No. 20 of 2001 }\end{array}$ & 1 to 4 Years & $\begin{array}{l}\text { Fporfeit } 50.000 .000,- \text { to } \\
\text { Rp 200.000.000,- }\end{array}$ \\
\hline 2 & $\begin{array}{l}\text { Law No. 23 of } \\
\text { 2004 }\end{array}$ & 4 to 5 Years & $\begin{array}{l}\text { Rp 12.000.000,- to } \\
\text { Rp 25.000.000,- }\end{array}$ \\
\hline 3 & $\begin{array}{l}\text { Law No. 18 of } \\
2013\end{array}$ & $\begin{array}{l}\text { 3 Monthsto 10 } \\
\text { Years }\end{array}$ & $\begin{array}{l}\text { Rp 500.000,- to Rp } \\
5.000 .000 .000,-\end{array}$ \\
\hline 4 & $\begin{array}{l}\text { Law No. 32 of } \\
\text { 2009 }\end{array}$ & 1 to 5 Years & $\begin{array}{l}\text { Rp 1.000.000.000,- } \\
\text { to Rp } \\
5.000 .000 .000,-\end{array}$ \\
\hline 5 & $\begin{array}{l}\text { Law No. 7 of } \\
\text { 1992 Jo. Law } \\
\text { No. 10 of 1998 }\end{array}$ & 1 to 7 Years & $\begin{array}{l}\text { Rp 1.000.000.000,- } \\
\text { to Rp } \\
10.000 .000 .000,-\end{array}$ \\
\hline 6 & $\begin{array}{l}\text { Law No. 23 of } \\
\text { 2002 Jo. Law }\end{array}$ & 2 to 5 Years & $\begin{array}{l}\text { Rp 20.000.000,- to } \\
\text { Rp 60.000.000,- }\end{array}$ \\
\hline
\end{tabular}




\begin{tabular}{|l|l|l|l|}
\hline & No. 35 of 2014 & \\
\hline 7 & $\begin{array}{l}\text { Law No. 35 of } \\
2009\end{array}$ & 1 to 6 Years & $\begin{array}{l}\text { Rp 40.000.000,- to } \\
\text { Rp 2.000.000.000,- }\end{array}$ \\
\hline
\end{tabular}

Based on the table above, it can be understood that a criminal sanction formulated in a specified minimum system is only imprisonment and forfeit. The minimum threshold of imprisonment and forfeit in each particular law varies. When it is understood globally, the specified minimum threshold of imprisonment in some special laws is from 3 months to 10 years. Then the minimum threshold of forfeit is from $\mathrm{Rp} 500,000$, - to $\mathrm{Rp}$ $5,000,000,000,-$

\section{B. Penalty Imposition in Specified Minimum Threshold}

The penalty imposition is the act of a judge imposing a penalty in court to the defendant, so it can also be referred to the in concreto penalty (penalination in concreto) [13]. Reference [3], [4] argues that if the definition of "punishment" is broadly defined as a process of granting or imposing a criminal by a judge, then it can be said that the penal system covers the entire provisions of legislation governing how the criminal law is enforced or operationalized concretely so that a person is obeyed sanctions (criminal law). This means that all statutory rules on substantive criminal law, formal criminal law and criminal law can be seen as a single functional penalty system in a broad sense. Whereas in the narrow sense, it only includes the rules/provisions of criminal law (substantive).

Thus, it is clear that penalty imposition can be called punishment or penalty in concreto, namely the process of granting or imposing sanctions in the form of criminal by judges in court. In the context of this discussion, the imposition of a criminal under specified minimum by a judge may be called concreto penalty. Being realted to the penalty imposition formulated with a specified minimum system in Indonesia, there is no single legislation governing it. The question is "Will the judge be allowed to impose a penalty under the specified minimum threshold in the law?".

Practically, the imposition of a penalty under a specific minimum threshold is based on the principle of freedom of the judge and the prohibition to reject the case on the grounds that the law is not present or is unclear. In the event that the law does not exist or is unclear, then the judge must conduct legal findings, even if necessary by using unwritten legal norms [5].

In accordance with this view, even though normatively the law has regulated the minimum threat of penalty, both imprisonment as well as forfeit, but in practice there are also judges which break the prescribed minimum by reason or consideration of social justice and moral justice [5].

More than just a philosophical reason that breaking through the specific minimum limits specified in the law is part of the performance of judges who are independent or free in finding a legal norm. The judge is not only a mouthpiece of the law, but also a legal form that gives shape to the contents of the law and adapts it to legal needs [5].
The issue of the practice of penalty imposition under specified minimum threshold, was discussed in the National Working Meeting of the Supreme Court with the Chief Justices of the High Court and certain District Court of Justice throughout Indonesia in Bandung on 14-19 September 2003. The meeting results different opinions [3], [4]:

1. The first group, the judge cannot impose a penalty under minimum threshold of the statutory penalty based on the argument of the principle of legality and for the sake of legal certainty;

2. The second group, the judge can impose a penalty under minimum statutory penalty law based on the principle of justice and the fact of the balance between the perpetrator's error rate and the condition.

Arief argues that in the absence of penalty rules or the application of minimum system (minimum), can cause unclear and even may arise misunderstanding about what is meant by the creator of law with minimum penalty inclusion in a formulation of offense. Does it mean adopting a fixed sentence model: MMS (Mandatory Minimum Sentence) which is absolute/imperative or embraces a relative/elastic/uncertain unfixed sentence model. In the special law there has never been a stipulation that the specified minimum penalty is a must/order to be applied in absolute terms. Thus, there is no affirmation of the MMS model [3], [4].

Thus it can be concluded that in essence a judge can impose a penalty under specified minimum threshold determined in the law because the law which determines the specified minimum penalty idoes not provide guidance. In imposing a penalty under the specified minimum threshold, the judge must be based on the aspect of justice and the fact of the balance between the perpetrator's error rate and the condition.

This is in line with the results of the 2009 National Working Meeting of the Supreme Court with the Bandung High Court [6], [10], which agrees that judges can impose penalty under minimum threshold supported by systematic, clear and logical legal evidence and considerations. The penalty under specified minimum threshold is casuistic and does not apply in general.

Harifin A. Tumpa explains that in principle the judge is obliged to implement the provisions arranged in the law, including the minimum penalty in the case of corruption. However, the principle does not apply rigidly. The judge is not a mouthpiece of the law, but the judge must also consider the sense of community justice. For example, a defendant threatened with Article 127 of Law no. 35 of 2009 [6].

Based on the legal fact revealed in court, the defendant is proven to be a relatively small number of users, then the judge decide in accordance with the indictment, but it can deviate from the specified minimum penalty by making fair consideration [2]. Artidjo Alkotsar states that the background to the determination of a specific minimum limit is the lack of trust in judges because there is usually a maximum limit. The basis for 
the imposition of a penalty under the minimum limit, namely the sense of justice by using a conscience [10].

The author agrees that the judge can impose an imprisonment under minimum threshold arranged in law because the judge is essentially not only law enforcement but also justice enforcer. Law enforced by the judge must be able to provide justice, so that justice is positioned above the law. The Constitution of the Republic of has clearly established that judicial power is an independent power to administer justice to uphold law and justice. Law and justice enforcement is based on Pancasila and Constitution of the Republic of Indonesia as referred to in Article 1 point 1 jo. Article 2 of The Law Number 48 of 2099 of Republic of Indonesia concerning Judicial Power (Law No. 48 of 2009).

In Indonesia, judicial power is conducted by a Supreme Court and the lower courts within the general judiciary, the religious court environment, the administrative court of the state, and by a Constitutional Court. In the context of criminal justice, the institutions/power bodies that administer the judiciary are the Supreme Court and the general court given the authority to examine and decide criminal cases. If it refers to the nature of the judicial power referred to in the constitution of the Constitution of the Republic of Indonesia, then the judge in the criminal justice must uphold law and justice. It means that criminal law enforced should be able to provide justice. If the judge of a penalty feels the law to be upheld unfairly, then it must dare to ignore or deviate.

Mahfud MD states that actually if the purpose of handling the case is not to seek a win, but to seek justice, the principle of law enforcement will be covered by itself. Therefore, people seeking justice will first waive the formal law if it is unfair [7]. Preparing for justice rather than law, it will bring about a law side with people and justice as one of the principal thoughts of progressive law[9]. The law must be side with the people. Justice must be positioned above the rules ("legal mobilization") if it does harm the people's sense of justice. The principle of side with people and justice are measured to avoid this progressive slump, misappropriation, abuse, and other negatives [7].

According to Radbruch, law is an element of culture, then like other cultural elements, the law embodies one of the values in the concrete life of man, namely the value of justice. From the statement it can be concluded that law only means as a law if the law is a manifestation of justice or at least an attempt in that direction [15]. Radbruch taught the concept of three basic legal ideas that some theorists and philosophy of law identified as the three objectives of law, namely justice, benefit, and legal certainty. For him, the three elements are the joint legal goals, namely justice, benefit, and legal certainty [1].

The three ideas of the basic element of law or the three objectives of the law will be contrary. Thus, Radbruch taught to use the principle of priority, which first priority is justice, then benefit, and finally the certainty. The use and certainty of the law should not be contrary to justice, as well as legal certainty should not be contrary to expediency [1].. If the conflict between the content of the law (legal certainty: Pen) and justice is so great that the legal order of law seems unfair, then the rule of law may be abandoned. [15].

According to [12], a qualified court decision exists not only because of the proficiency in applying the law to a case, but also because of the judge's ability to reconstruct justice in the community, both justice for victims, perpetrators and society. A professional judge of criminal law is not only an enforcer and inventor of the law, but it must predict what happens after the verdict has been decided, namely whether the community obeys the rule or otherwise, how the impact of decisions for the perpetrators and the victims both in short and long time.

In applying the law, the judge must seek to discover or create law, and provide a legal solution to the dispute or matter in which it is handled. Thus, it can be understood that in the process of examining, adjudicating and deciding cases, the criminal judge is obliged to apply the law, find the law and at the same time be able to bridge the legal justice with the community justice (in this case the perpetrator, the victim, and the society) and moral justice in order to create justice because the real meaning of "judging" in the context of a judge is to create something fair or justice [12].

From the discussion above, it can be understood that penalty imposition under specified minimum threshold arranged in law by a judge is allowed, in line with the relative/elastic/uncertain untioned sentence model. Penalty imposition under minimum is casuistic and its consideration is based on justice aspects and the fact of balance between the perpetrator's error rate and the condition. In imposing the penalty, the judge is not only a mouthpiece of the law, but it must consider the sense of community justice. It is in line with the mandate of the constitution (the Constitution of the Republic of Indonesia) that judges as judicial authorities have the duty to uphold law and justice. If the specified minimum penalty arranged in the law seems unfair to be applied to the perpetrator (the defendant), the judge may deviate by imposing a penalty under a specified minimum penalty. Penalty imposition under specified minimum applies to imprisonment and forfeit in the special law.

\section{CONCLUSION}

Based on the description above, it can be concluded that at a practical level, imposition of a penalty under a specific minimum limit can be made. It is based on the aspect of justice and the fact of balance between the level of wrongdoers and the circumstances surrounding them. In assessing the fairness and failure of the perpetrator, the judge must use his conscience. The imposition of a penalty under a specific minimum is not universal, but is casuistic. This means that not all criminal cases that are threatened with a special minimum system in a law can be subject to a penalty below the minimum limit. 


\section{REFERENCES}

[1] Achmad Ali, Menguak Teori Hukum (Legal Theory) dan Teori Peradilan (Judicialprudence) Termasuk Interpretasi Undang-Undang (Legisprudence), Kencana, Jakarta, 2012.

[2] Andi Saputra, MA Sepakati Vonis UU Narkotika Boleh Di Bawah Ancaman Minimal, Available: http://m.detik.com/news/berita/3096560/ma-sepakativonis-uu-narkotika-boleh-di-bawah-ancaman-minimal.

[3] Barda Nawawi Arief, Bunga Rampai Kebijakan Hukum Pidana (Perkembangan Penyusunan Konsep KUHP Baru), Kencana, Jakarta, 2014.

[4] Barda Nawawi Arief, Kebijakan Formulasi Ketentuan Pidana dalam Peraturan Perundang-Undangan, Penerbit Pustaka Magister, Semarang, 2012.

[5] Ismail Rumadhan, Penafsiran Hakim Terhadap Ketentuan Pidana Minimum Khusus dalam Undang-Undang Tindak Pidana Korupsi, Jurnal Hukum dan Peradilan Volume 2 Nomor 3 November, 2013, pp. 379-404.

[6] Lex Regis, Hakim Boleh Menjatuhkan Vonis Di Bawah Syarat Minimal, Available: http://www.lexregis.com/?menu=news\&idn=all.

[7] Mahfud MD, Membangun Politik Hukum, Menegakkan Konstitusi, Rajawali Pers, Jakarta, 2012.

[8] R. Soesilo, Kitab Undang-Undang Hukum Pidana (KUHP) serta Komentar-Komentarnya Lengkap Pasal Demi Pasal, Politiea, Bogor, 1995.

[9] Romli Atmasasmita, Teori Hukum Integratif (Rekonstruksi Terhadap Teori Hukum Pembangunan dan Teori Hukum Pembangunan), Genta Publishing, Yogyakarta, 2012.

[10] Sadriyah Mansur, Penjatuhan Pidana Di Bawah Ancaman Pidana Minimum dari Ketentuan Undang-Undang Nomor 35 Tahun 2009 tentang Narkotika, Madani Legal Review Vol. 1 No. 1, Juni 2017, pp. 90-110.

[11] Shidarta in the Mahfud MD et.al., Dekonstruksi dan Gerakan Pemikiran Hukum Progresif, Thafa Media, Yogyakarta, 2013.

[12] Sri Sutatiek, Menyoal Akuntabilitas Moral Hakim Pidana Dalam Memeriksa, Mengadili, dan Memutus Perkara, Aswaja Pressindo, Yogyakarta, 2013.

[13] Sudarto, Hukum dan Hukum Pidana, Bandung, Alumni 2007.

[14] Teguh Prasetyo dan Abdul Halim Barkatullah, Politik Hukum Pidana (Kajian Kebijakan Kriminalisasi dan Dekriminalisasi), Pustaka Pelajar, Yogyakarta, 2012.

[15] Theo Huijbers, Filsafat Hukum Dalam Lintasan Sejarah, Kanisius, Yogyakarta, 1982. 